$\mathrm{RI} / \mathrm{IR}$

Wood, G., Szamosi, L.T., Psychogios, A., Sarvanidis S. and Fotopoulou (Forthcoming), Rethinking Greek Capitalism through the Lens of Industrial Relations Reform: A View until the 2015 Referendum. Relations industrielles/Industrial Relations

\title{
Rethinking Greek Capitalism through the Lens of Industrial Relations Reform: A View until the 2015 Referendum
}

\section{Geoffrey Wood, Leslie T. Szamosi, Alexandros Psychogios, Sofoklis Sarvanidis, and Dialechti, Fotopoulou}

\begin{abstract}
This paper explores changes in Industrial Relations (IR) regulation and practice in a context of institutional crisis and change. The existing literature on industrial relations in Greece highlights a long process of deregulation that has been accelerated since the onset of the economic crisis, and the inherent segmentation of the Greek system between regulated players and largely unregulated informal and SME players. Radical neo-liberal reforms have weakened the position of those most reliant on traditional regulatory arrangements: larger formal sector employers and their workers, making the basis of Greek competitiveness more fragile. At the same time, the system cannot be dismissed as simply dysfunctional: key elite interests have done well from weak and uneven institutional coverage and have much to gain by reduced government capabilities. At the time of writing, the Greek IR system is being impelled in one direction by external pressures and elite interests, and another by a grassroots counter-movement; whilst the solutions to the Greek condition may be political, the realm of political action is circumscribed by long historical legacies.
\end{abstract}

Keywords: Greek capitalism, varieties of capitalism, capitalist diversity, austerity, institutional change, elite theory. 


\section{Introduction}

There has been a growing body of work on IR in Greece, which has highlighted the nature and extent of structural crisis and systemic liberalization (Kornelakis and Voskeristian, 2014; Zambarloukou, 2010). A common strand running through such work is that Greece has undergone shifts towards lighted regulation, but without the complementarities normally associated with mature Liberal Market Economies (LMEs,ibid.). In contrast, based on the most recent developments in Greece, and ongoing advances in the theoretical literature on comparative capitalism, we highlight not only institutional changes, but also long continuities, continuities that set Greece apart from both 'disorganized' LMEs and other Mixed Market Economies (MMEs), making for an industrial relations system with some quite distinct features.

It can be argued that in examining issues of institutional change and labour market regulation, there has been a tendency to either neglect politics, or assume that the hollowing out of politics is a foregone conclusion, making liberalization inevitable (c.f. Streeck, 2011); in contrast, the accession to power of Syriza would indicate that political counter-movements may indeed make real advances, even if durable compromises or solutions remain elusive. Once more, as recent advances in elite theory alert us, when military elites are able to secure a persistent influence in national life, socio-economic realities will differ from other countries with broadly similar institutional arrangements in other respects (Priestland, 2012). Hence, this paper highlights the limitations of conceptualizations of the role of the state that simply depict it as retreating or struggling to manage markets; it draws out the consequences of excessive and partially concealed defence spending for other areas of the economy, and, by extension, for work and employment relations. This is a feature that sets Greece apart from MMEs, but has relevance for other national contexts where military ambitions outstrip economic capabilities, and where relations with the military have been quite effective in accessing resources, austerity elsewhere notwithstanding. In other words, unlike other MMEs, in Greece the sovereign debt crisis was not only due to the state shouldering the debts run up by an irresponsible banking sector, but owing to over-borrowing to support unsustainable levels of defence spending. Not only is the latter likely to crowd out investment in other areas of the economy (Scott, 2001; Kollias and Paleologou, 2010), but it also made the crisis, and the scale and depth of current reforms, particularly severe. Again, due to 
long historical legacies, key economic elites have only selectively engaged with the national system (Close, 2014). Due to the extreme fluidity of the situation being faced in Greece at this time and the particularly 'quick' outdating of information, this research focuses on publically available information, complemented by recent theoretical advances within the broad literature on comparative capitalism and elite theory.

\section{Varieties of Capitalism and the Greek 'Mixed Market' Capitalism}

The original Varieties of Capitalism (VoC) approach (Hall and Soskice, 2001) divides developed countries into Liberal (LME, e.g. US and UK) and Coordinated Market Economies (CME, e.g. Scandinavia, Germany, Japan). Hall and Soskice (2001) held that other capitalist archetypes lacked the known complementarities encountered in them, and hence would ultimately converge in the direction of one or the other. Later work conceded that convergence was neither a smooth nor inevitable process and that other societies had distinct and persistent institutional features (and, indeed, pockets of advantage) in their own right (Amable, 2003; Hancké et al., 2007).

More recent developments and extensions of the VoC approach developed further archetypes. Hall and Thelen (2006) suggest that the economies found in Southern Europe, constitute an archetype in their own right, the "mixed market economies" (MMEs), which include Spain, Portugal, Italy and Greece. These economies show a "mixed market regulation with a degree of coordinated, relational arrangements" (Nash, 2011: 230). In other words, they have been classified as being in-between two mature archetypes of the VoC model (Hancké et al., 2007). The term MME is not an unproblematic one in that CMEs also combine elements of state and market. Nonetheless, this is a term that has gained some currency, and hence is one deployed through this article.

In a recent Relations industrielles/Industrial Relations paper, Kornelakis and Voskeritsan (2014: 344) argued that reforms would "transform Greece into a dysfunctional market economy." The political backlash against the reforms, and the accession to power of Syriza in 2015, have highlighted the extent to which top-down reforms may be halted or even reversed, and the essential dynamism and volatility of 
the Greek system jeopardized. At the same time, Kornelakis and Voskeritsan (2014) focused on the formal mechanisms of regulation and policy reforms up until 2011; they acknowledge, however, that a key feature of Greece is not so much the regulatory reforms, but how there can be a persistent disarticulation between regulatory features and actual firm level practices. This would suggest that formal regulatory reforms may, in reality, have a very uneven impact on actual firm behaviour, especially SMEs and underground economies. Hence, a primary focus of this article is on the inherent and persistent segmentation of the Greek economy-and on changes since 2011 up until the acceptance of the third bailout terms following the 2015 referendum — complementing this earlier detailed study of changes of regulatory features.

MMEs are characterized by a large agricultural sector, long history of state intervention and relatively deregulated IR (c.f. Hall and Soskice, 2001: 21). In addition, MMEs are not based on skill intensity but rather on their ability to meet changes in market demands (Amable, 2003). As in other Mediterranean countries, Greece relies heavily on regulation (Casey, 2009) and the state plays a predominant role in various aspects of the national economic development such as the relationships between firms, the relationships between firms and financial capital and the determination of industrial relations outcomes, education, etc. (Schmidt, 2002; Zambarloukou, 2006; Fotopoulou, 2014). According to Zambarloukou (2010), another feature of Greece is the inefficient coordination within the economy and labour market which is mainly related to the large number of small and medium-sized enterprises (SMEs). Similarly with other MMEs, like Spain and Italy, Greece appears to have a misfit between labour institutions and lack of institutional complementarities (c.f. Molina and Rhodes, 2007: 225-226). In other words, in MMEs, there is a history of the state playing an extensive regulatory role; there is also a lack of developed institutional complementarities, especially in relation to welfare and educational provisions (Hancké et al., 2007; Amable, 2003; Hall and Soskice, 2001). The limited welfare provision increases the need for attachment to job security (Featherstone, 2008). In MMEs, a unionized employee voice is strongly reliant upon the provisions of a legislative framework (see Regalia, 1995; c.f. Marginson and Sisson, 2006). Hence “[...] legal enactment has been prior and collective bargaining secondary, reflecting the 
pervasive role of the state in economic and social affairs [...]" (Marginson and Sisson, 2006: 43).

Whilst the MME categorization is a very broad one, there is little doubt that the Greek economy has all these features, albeit sometimes in an exaggerated form (c.f. Psychogios et al., 2010; Psychogios and Wood, 2010). This has led some writers to suggest that it is somewhat hard to categorize economies such as Greece that appear to be shifting towards a "defamiliarized" and more liberal model (Kornelakis and Voskeritsan, 2014). This argument is also supported by recent work in the comparative institutional tradition that has highlighted the extent to which institutions are not always as closely coupled as commonly presumed (Lane and Wood, 2009) nor is the coverage of national institutions necessarily complete (ibid.). In this respect, within any national context, there are areas of economic activity and social groupings that may become decoupled from dominant ways of doing things nationally. There are two forms of such decoupling which may be assumed.

The first is that whilst there is an inevitable clustering of institutions at the national level, regional and sectoral institutions may make for alternative sets of complementarities (ibid.). A cluster of firms-or even, a single large firm-may create alternative sets of local institutions (Crouch et al., 2009: 672). Firms may opt away from the dominant national paradigm, orientating themselves towards regional or sectoral specific structures (ibid.). Such a process may be aimed at either compensating for national systemic "pathologies" or an attempt to build on regional strengths (Sorge, 2005: 245).

A second process is institutional drift, whereby regions or social groupings become partially decoupled not so much as a conscious remedy for institutional failings at the national level, but because dominant interests gradually marginalize or discard those interests and groupings that are seen irrelevant to their own accumulation (Jessop, 2012). In turn, players may seek to at least partially exit from the system because the burdens imposed (i.e., the taxes or formal employment regulation) appear greater than the benefits of participation. 
From a social system of production starting point, Amable (2003) argues that what he terms as the Mediterranean model is neither temporary nor transitional, but may persist and evolve on distinct lines. Such countries have some advantages in labour intensive industries sensitive to wage costs, such as textiles and rubber products (Amable, 2003: 205; c.f. Kyrgidou and Spyropoulou 2013); whilst many emerging markets may have even lower costs, they lack the market access Mediterranean enjoy as members of the EU. Whilst the hands-off employment policies, and low investment in vocational training, that characterize them is rather akin to LMEs (Amable, 2003: 140), in Mediterranean economies, this is combined with more regulated product markets, a tradition of higher levels of state command and control regulation, and with their associated administrative and regulatory burdens (Amable 2003: 120).

Schmidt (2002) provides an alternative_-but broadly similar typology—that of 'Stateinfluenced Market Economies' (Schmidt, 2007), which, devotes more attention to industrial relations issues. In State-influenced Market Economies, inter-firm and employment relationships are characterized by high levels of state mediation, but also adversarialism as was the case in Greece, at least until the onset of the 2008 crisis (Featherstone, 2008). Jessop (2012) argues that, whilst national specificities persist, at particular moments, a set of ideologies and practices may attain eco-systemic dominance; currently, this is neo-liberalism, and hence, any changes in the Greek system in response to crisis are likely to be in this direction.

Featherstone (2011) argues that successive Greek governments had failed to deal with structural problems of competitiveness, and gross imbalances in both investment and trade, making the economy highly vulnerable to external shocks. The 2008 economic crisis resulted in the country being placed under an unprecedented degree of "external monitoring and policing" by the International Financial Institutions and the EU (Featherstone, 2011: 193) arguably on a more thorough level than other crisis-ridden EU states. In turn, the imposition of these measures raise questions of state legitimacy and governability which may have unforeseen future consequences (Featherstone, 2011).

\section{Elite Composition and the Greek Crisis}


Indeed, the scale of the crisis, which was even worse than those suffered by Spain, Portugal and Ireland might suggest that Greece is a rather extreme case. On the one hand, it could be argued that Greece's large underground economy and institutional complexities suggest that it has more in common with the transitional economies of the Balkan countries than more developed Mediterranean economies (Antonopoulos, 2008; Psychogios and Szamosi, 2007). On the other hand, Greece is distinct from both other MMEs and the other Balkan states by the structural nature of its crisis. One of the most remarkable aspects of the present condition has been the haste with which the blame for banking sector misconduct has been glibly shifted onto the state: crises which, in Ireland, Spain and Italy, started in the banking sector have been swiftly and carelessly labelled as sovereign wealth crises, despite the fact that the latter were commonly caused by hasty bank bailouts. In contrast, and uniquely, the Greek crisis is, to a large extent, a genuine sovereign wealth one.

As Dunne et al. (2001) note, for many years, owing to antipathy to Turkey, Greece has borne extraordinarily high levels of defence spending; easy credit was extended by West European banks at the prompting of their governments in order to bolster their domestic arms industries. Such spending was very much higher as a proportion of GDP than other NATO and EU states; at the end of the Cold War, most countries cut back on arms spending, but in the case of Greece it actually increased leading, in turn, to extremely high levels of government debt (Kollias et al., 2004). According to World Bank (2014) data, prior to 2008 Greece was spending 2.7\% of GDP on military spending which increased to $3.0 \%$ and $3.2 \%$ in 2008-2009 respectively; in 2012 and 2013 these were $2.4 \%$ and $2.5 \%$ respectively. In contrast, Italy and Spain have maintained $2 \%$ and $1 \%$ respectively for the last 10 years while Italy has dropped from $1.8 \%$ to about $1.5 \%$ of GDP.

As Lynn (2010: 118) notes, a large amount of such debt was "systematically concealed in the interests of national security"; this 'fiddle' meant that Greece's debt situation was very much worse than initially anticipated, making for particularly painful adjustments. Moreover, an excessive investment on defence has crowded out investment in other areas, worsening structural distortions in the Greek economy, and, thus, indirectly contributed to the unbalanced nature of the labour market (c.f. Kollias and Paleologou, 2010). The partially concealed nature of defence spending has further 
created ample opportunities for corruption, which may spill over into other areas of the economy; there is much evidence that high military spending worsens corruption (Gupta et al., 2001). Ironically, despite it having helped cause the Greek crisis, spending on the Greek military has not been curtailed to the same extent as other areas of the public sector (Drakoularakos, 2014); indeed, defence spending on equipment remains opaque (Dempsey, 2013), providing a fertile avenue for corruption, and degrading economic life at large. Priestland (2012) argues that elites are typically composed of three factions: militarists; merchant/capitalists; and savants. Only when the former two are discredited do the latter attain predominance, and enact policies that entail genuine social compromises. Whilst there is little doubt that capitalist elites and the solutions they have promulgated are now largely discredited with a large component of the Greek electorate, the militarists retain considerable political influence and clout, whilst weaker governmental regulatory capabilities make it harder to reign in less responsible economic interests.

\section{The Role of Enterprises in the Greek IR System}

In common with other MMEs, there is a pronounced dualism of labour markets and welfare institutions (Zambarloukou, 2010), where a large number of Small \& Medium Enterprises $\left(\right.$ SMEs) ${ }^{1}$ exist (i.e., in the Greek case nearly two-thirds of total employment (c.f. Mulhern, 1995 and Kritsantonis, 1998). Most firms are family owned and managed by their founders or by small proprietors (Galanaki and Papalexandris, 2005; Mihail and Elefterie, 2006; Vouzas, 2004) and the ownership structure allows for the concentration of power and control within a few large holders (Vasiliou and Daskalakis, 2009). According to Amable (2003), in contrast with the Continental European model which emphasizes social protection, the Mediterranean model is based on employment protection. Nevertheless, employment protection legislation is in formal terms one of the strictest across the OECD countries (OECD 2007, 2008 and 2009; c.f. Kretsos, 2011a: 458 and 2011b: 265), enforcement is generally inconsistent, incoherent and ineffective (Mihail, 2003; Psychogios et al., 2010; Psychogios and Wood, 2010; Zambarloukou, 2007 and 2010). Indeed, the violation of labour law is considered an 'endemic phenomenon' for the majority of

\footnotetext{
${ }^{1}$ This study follows the definition of SMEs adopted by the European Commission (2003/361/EC). In particular, it distinguishes Medium-sized companies (<250 Employees and 50m Turnover), Small companies (<50 Employees and 10m Turnover) and Micro companies (<10 Employees and 2m Turnover).
} 
enterprises in the private services sector (Kretsos, 2004; c.f. Kretsos, 2011b: 276). Where unions are absent, rights are particularly weak (Zambarloukou, 2007 and 2010) and in particular for SMEs (Mihail, 2004: 550). In any event, firms with less than 20 employees (97\% of Greek firms) are not obliged to recognize unions representative of their workforce (Kouzis, 2007; Kretsos, 2011b; Matsaganis, 2007). Indeed, it has been argued that worker rights are more precarious in Greece than in other MMEs (Mihail, 2003; c.f. Psychogios and Wood, 2010).

It is widely noted that many Greek SMEs hire and pay employees in the form of undeclared work (Kretsos, 2004; Kouzis, 2009), evade taxation (Kapsalis, 2007; Kouzis, 2007; Psychogios and Wood, 2010), and generally ignore labour law legislations (Mihail, 2004), even if they are formally constituted enterprises. In contrast, large enterprises are highly regulated, and heavily unionized and since the onset of the crisis, many have engaged in large-scale job shedding (Hyman, 2010). After the agreement to the last bailout, the present Greek left government "committed" to $50 €$ billion in the sale or winding down of state owned assets (The Guardian, 2015; Reuters, 2015). This means that the more regulated component of the Greek economy (bar the military complex and allied firms) is likely to shrink with the unregulated component assuming greater importance.

\section{Towards the Liberalization of Industrial Relations}

\section{Labour Market Deregulation}

In 2010 in collaboration with the European Union (EU), the International Monetary Fund (IMF) signed the Memorandum of Economic and Fiscal Policies (MoF-Law $3845 / 2010 \mathrm{a}, \mathrm{b})$, starting a process of labour market deregulation, since the structure of the Greek labour market was the major barrier for growth of the Greek economy (Koukiadaki and Kretsos, 2012). In this respect, the target was a drastic reduction of labour costs and deregulation and liberalization. Various significant aspects of Greek labour law have been revised with major consequences both for the role of the state and the actors of the IR system (Koukiadaki and Kretsos, 2012). The labour law reform has been designed to address both the results of the international financial crisis and Greece's own fiscal problems. In addition, the austerity measures of previous Greek governments, as imposed by the IMF and EU, have instituted significant and dramatic changes in employment policy. More specifically, 


\section{$\mathrm{RI} / \mathrm{IR}$}

“[...] the measures proclaimed by the initial and consequent bailout agreements stipulated among others wage cuts, pay freezes, massive dismissals in the public sector, restructuring of public enterprises, lower minimum wages for young workers and increase in retirement age [...]" Kretsos (2011b: 268).

The new employment relations challenge the coverage of existing collective agreements. The reforms seek to promote the decentralization of collective bargaining (Kretsos, 2011b: 268). Collective agreements were substituted with individual or firm-specific contracts (Law 4024/2012). At the same time, the structural program adopted in February 2012 (Law 4046/2012) replaced the possibility of indefinite collective agreements between 1 and 3 years (Dedoussopoulos et al., 2013). Moreover, the law on redundancies became less strict by lowering the level of severance pay and by giving the opportunity to employers to give half of the severance pay to employees so long as they provided a written warning a few months earlier (ranging from two to six months depending on the number of working years with the current employer). The minimum wage experienced a $22 \%$ cut for employees over 25 years of age and 32\% for those under 25 (Matsaganis, 2012). Finally, there was a suspension of bonuses from public sector employees and wage freezes (European Commission, 2015). These reforms mostly affected those with "good" jobs at larger organizations: non-unionized employees are not practically covered by any sort of union-based collective agreement (Kokkaliari, 2010a; Kretsos, 2011b).

\section{Working Conditions}

The employment laws (e.g., 3845/2010, 3863/2010, 4039/2012 and 4152/2012) also changed the regulation of working time, moving away from the standard level of eight hours hitherto promoted. Additional remuneration rates for overtime have also been cut. The working week has been extended from five to six days for private and public workers, without an additional wage increase, job cuts seem to have also led to work intensification with longer hours in many services for remaining public sector employees while overtime rates have been reduced (European Commission, 2015). It is a widespread view amongst trade union officials that the new legislative context allows "the employers to unilaterally define and adjust the number of working hours" (Kokkaliari, 2010a: 34). It also became easier for employers to make use of temporary 
or part-time workers, whilst the provisional period of a probationary employment was extended.

\section{The Changing Role of Mediation and Arbitration}

One of the most critical and challenging issues is the future role of the OMED. As has been noted in the past, it played a significant role in advancing worker rights. Its reputation as being 'worker friendly' has been diluted under the new law (i.e., 3899/2010). The latter significantly reduces the scope of the arbitration procedure at the expense of employees, whilst Law 4093/2012 makes the whole procedure simpler and faster for the benefit of the employer. In particular, only issues related to salaries and remuneration per hour can now be included within the remit of the arbitration process, whereas other terms and conditions (e.g., bonuses, compensation rates, and other benefits) that were typically part of this process are now excluded (INE/GSEEADEDY, 2010: 299-300).

\section{Collective Redundancies and Job Losses}

New employment legislation allows greater flexibility in favour of the employers with regard to redundancies and compensation rates by changing the rules of collective dismissals (c.f. Kretsos, 2011b). More specifically, the compensation rate has been reduced up to $50 \%$ as soon as the employer gives advanced notice. Henceforth, according to the recent labour law reform, the period of notice is: a- one month for those that are employed from 2 months to 10 years; b- two months for those that are employed at least 10 years; c- three months for those that are employed at least 15 years; $d$ - four months for those that are employed at least 20 years; and e- six months for those that are employed more than 20 years (Kokkaliari, 2010b: 4). In addition, according to the new employment law, organizations with at least 150 employees can dismiss up to $5 \%$ of the workforce and no more than 30 employees, whereas before the enactment of the legislation the corresponding quota was 2\% (maximum limit) (Kokkaliari, 2010b).

\section{Rethinking Greek Capitalism}

Greece currently is moving between two major groups of institutional drivers through which its capitalistic system can be understood. The first group is related to the traditional institutional logics of the system, namely the underground economy 
(Katsios, 2006); the predominance of SMEs (Mulhern, 1995;Kritsantonis, 1998; Psychogios and Wood, 2010) that mainly operate on a national rather than international level (Kornelakis and Voskeristian, 2014); the adoption of informal management and organizational practices (Psychogios and Szamosi, 2007), and the poor capabilities of the state (Psychogios et al., 2008). The second group is related to the imposed institutional changes, attempting to respond to the crisis and make the system more liberalized (Kyrgidou and Spyropoulou, 2013; Koukiadaki and Kretsos, 2012). These two seem to have created a context of institutional complexity that can decouple action from structure in terms of adopting more liberalized IR practices. For example, changes in the IR system have been targeted at liberalizing Greek capitalism. These changes can be understood in the following phases.

In the initial phase (May 2010 to December 2010) of IR reform, changes in the individual labour law and the collective bargaining process were introduced. In the second (December 2010-October 2011), further legislation was introduced (Law $3899 / 2010$ ) that established the mediation and arbitration process of collective bargaining (Voskeritsian and Kornelakis 2011). From October 2011 to June 2012, collective bargaining had been further decentralized reaching the level of companies and industries (Law 4024/2011); this triggered more social and political resistance (European Commission, 2014). From June 2012 until December 2014 there was another change in the IR system. During this period, the second memorandum was ratified and more legislation emerged targeting to liberalize the IR system (Law 4046/2012; 4152/2012). This phase was characterized by a stabilization of the system which the European Commission (2014) indicated that substantive implementation had occurred, goals were generally being met, and wages were in better alignment with productivity and costs; however, phase four came to a dramatic 'halt' with the January 2015 election of a left government and the introduction of dramatic turbulence back into the system (Financial Times, 2015) - termed Phase Five. It brought in legislation that sought to halt austerity (Bird, 2015). It can be argued that these waves of reforms had the consequences of weakening the position of those firms most closely engaged with formal institutional arrangements, leaving the large informal sector, the offshore activities of the "unpatriotic" capitalist elite (periodic promises of tax crackdowns notwithstanding) and the machinations of the militarists largely unscathed. The Greek system cannot, however, be dismissed as dysfunctional: 
clearly, it continues to work quite well for certain economic interests, even if the reforms have left most workers worse off, and enhanced occupational and job insecurity.

Although it has often been argued that neo-liberal interests welcome such periods of "creative destruction" in that they open the opportunity for the permanent destruction of structures that might mediate markets and facilitate the capture of resources by a new entrepreneurial class (invariably oligarchs) (Klein, 2007), such processes can, in some circumstances, leave existing elites completely discredited, and open opportunities for new political actors or movements. Whilst the latter are not invariably progressive, there is a growing number of examples (mostly in Latin America), where reckless liberalization has led to the ascendency of the radical left. At the time of writing, it is unclear whether the current Left Government will be able to realize its agenda, and, in any event, there seems little sign of a speedy resolution to Greece's structural challenges.

Hence, whilst it has widely been argued that all countries are to a lesser or greater extent liberalizing (Streeck, 2011), Greece is being pulled in two distinct directions, reflecting both the durable strength of key interest groupings who have little interest in better institutions and external pressures to liberalization on the one hand, and political counter-movements on the other hand. Although the military elite should bear a significant proportion of the blame for the Greek crisis, they continue to commandeer a disproportionate amount of state resources, whilst corruption surrounding defence spending does little to promote transparency elsewhere across the economy. Meanwhile, the capitalist elite are distinguished by their tendency to evade fiscal responsibility, again, a long legacy of a weak and at times, repressive, state tradition (Close, 2014); nowhere is this better evidenced than the Greek-owned merchant marine, one of the largest in the world, but largely flagged abroad in regulatory and tax havens. In turn, this makes it very difficult for even a progressive Greek government to promote social compromise, and to promote greater responsibility and engagement with the system among smaller economic players.Hence, liberalization has done little to erode systemic dualism, other than further weakening the position of those firms more closely engaged with, and who have built their competitiveness on, existing institutional arrangements. 
But, how can the Greek system work better? Kornelakis and Voskeristian (2014) suggest that if the imposed institutional changes do not take account of the traditional institutional logics, they will fail: the whole effort of deregulating the IR system, intended to make the Greek business environment more attractive for foreign direct investments, will be of limited to no importance. In other words, there needs to be more thought as to what was the basis of competitiveness of those Greek and foreign firms that benefitted from existing institutional arrangements, and who provided "good" jobs for their workers, and how this can be preserved during a period of reform. Yet, it can be argued that a limitation of institutional theories is a tendency to focus on the gap between the present and the desirable, with only limited attention being accorded to how they may be bridged. Greece may be impelled in one direction by a progressive movement from below, but it is driven in another by external pressures, and, at home, by militarists and "unpatriotic" elites, who have little interest in stronger regulation, and who may well be served by weaker governmental capabilities.

\section{Conclusions}

In theoretical terms, this paper highlights the need to take account of the composition of elites in understanding both institutional path dependence and change, and the uneven and partial nature of what constitutes institutional functionality: systems that may appear in many respects dysfunctional may work rather well for specific economic interests. Indeed, it can be argued that institutional arrangements invariably incorporate some or other functionalities for particular sets of actors, or they would not emerge or persist at all. Although Greece has much in common with other MMEs, and indeed surrounding Balkan states, what sets Greece apart (with the possible exceptions of Serbia and Kosovo) is the disproportionate funnelling of state resources to the military, not only making for a genuine sovereign wealth crisis (as adverse to a bank inflicted one), but also less state spending in other areas, a crowding out of investment, as well as additional opportunities for corruption. In turn, this has reinforced the dualism in the economy. Whilst there has been a tendency to view states as retreating in the face of markets, in Greece the situation is more complicated. For example, Greek governments have persistently committed to excessive defence spending that has consistently outstripped resource capabilities, worsened by Western 
European governments who encouraged their banks to extend easy credit to the Greek state to bolster up their arms exports. Although with the latest agreement this has been addressed somewhat (Wall Street Journal, 2015) it is still disproportionate. This is a further example of why the Greek case is a unique one that cannot be easily categorized as a 'dysfunctional' liberal market economy (Della Sala, 2008; Kornelakis and Voskeristian, 2014) or MME (Amable, 2003) that is characterized by an inevitable retreat from statism.

There is little doubt that present Greek institutions are both weak and dysfunctional in terms of regulating labour markets, and, indeed, for securing viable and sustainable growth, even if they continue to work quite well in meeting the interests of both militarists and "unpatriotic" economic elite; indeed, reduced governmental capabilities make it inevitably more difficult to hold the latter to account. A long period of institutional drift caused by this type of capitalism, as local dominant elites battle to amend the system in order to cope with long term shifts in the capitalist economy, may result in such elites narrowing their focus on to their own immediate concerns which can easily be accommodated through liberalization of large areas of the economy, a process that Jessop (2011) argues is characteristic of the global neoliberal ecosystem. In short, smaller and more marginal players may both be pushed further out of the system (either through benign neglect or systematic exclusion) and actively choose to withdraw. This vests the organized labour and other civil society associations with great historic importance. In the absence of coherent policy alternatives, the role of trade unions is likely to remain defensive, mounting desperate rear-guard actions in order to shore up a decaying existing order. Whilst this vests national politics with great importance, it is as yet unclear if the current (2015) Greek government will be able to ameliorate external pressures and solve the problem of Greece's elite.

\section{Acknowledgement}

The authors are indebted to the insightful comments and insights of the anonymous referees.

\section{References}


Amable, Bruno. 2003. The Diversity of Modern Capitalism. Oxford: Oxford University Press.

Antonopoulos, Georgios A. 2008. "The Balkans as a Laboratory (for the Study) of Organized Crime". Trends in Organized Crime, 11 (4), 315-325.

Bird, Mike. 2015. "Greece Blinked and its Past 6 Months Have been a Waste." Business Insider. July 10, 2015.

Casey, Terrence. 2009. "Mapping Stability and Change in Advanced Capitalisms." Comparative European Politics, 7 (2), 255-278.

Close, David H. 2014. Greece Since 1945: Politics, Economy and Society. London: Routledge.

Crouch, Colin, Martin Schröder and Helmut Voelzkow. 2009. "Regional and Sectoral Varieties of Capitalism". Economy and Society, 38 (4), 654-678.

Della Sala, Vincent. 2008. "The Italian Model of Capitalism: On the Road between Globalization and Europeanization?" Journal of European Public Policy, 11 (6), 1041-1057.

Dempsey, Judy. 2013. "Military in Greece is Spared Cuts", New York Times, 7 January 2013. http://www.nytimes.com/2013/01/08/World/Europe/08ihtLetter08.Html?_R=0.

Dedoussopoulos, Apostolos, Valia Aranitou, Franciscos Koutentakis and Marina Maropoulou. (2013). Assessing the Impact of the Memoranda on Greek Labour Market and Labour Relations. (No. 483774). International Labour Organization.

Drakoularakos, Stavros I. 2014. "Financial Crisis and Defence Cuts: The View from Greece", Security Observer, 29 January 2014. http://Securityobserver.Org/FinancialCrisis-and-Defence-Cuts-The-View-From-Greece/.

Dunne, Paul, Eftychia Nikolaidou and Dimitrios Vougas. 2011. "Defence Spending and Economic Growth: A Causal Analysis for Greece and Turkey", Defence and Peace Economics, 21 (1), 5-26.

European Commission. 2003. (/361/EC). "Commission Recommendation Of 6 May 2003 Concerning the Definition of Micro, Small and Medium-Sized Enterprises." Notified under Document Number C(2003), 1422.

European Commission. 2014. Second Economic Adjustment Program for Greece: $4^{\text {th }}$ Review. April. Directorate-General for Economic and Financial Affairs: Brussels.

European Commission. 2015. Industrial Relations in Europe 2014. DirectorateGeneral for Employment, Social Affairs and Inclusion: Brussels.

Featherstone, Kevin. 2008. "Varieties of Capitalism and the Greek Case: Explaining the Constraints on Domestic Reform". Greece Paper No 11, Hellenic Observatory, Papers On Greece and Southeast Europe.

Featherstone, Kevin. 2011. "The Greek Sovereign Debt Crisis and EMU: A Failing State in a Skewed Regime." Journal of Common Market Studies, 49 (2), 193-217.

Financial Times. 2015. "Statesman or ideologue-Tsipras has to choose." July 11, 2015 (online).

Fotopoulou, Dialechti. 2014. The Case of MBAs in Greece: Their Impact on Managerial Practice. Saarbrucken: LAP Lambert Academic Publishing.

Galanaki, Eleanna and Nancy Papalexandris. 2005. "Outsourcing of Human Resource Management Services in Greece". International Journal of Manpower, 26 (4), 382396.

Gupta, Sanjeev, Luiz De Mello and Raju Sharan. 2001. "Corruption and Military Spending", European Journal of Political Economy, 17 (4), 749-777.

Hall, Peter A. and David Soskice. 2001. "An Introduction To Varieties Of Capitalism". In Hall, Peter A. and David Soskice (Eds.) Varieties Of Capitalism: The 
Institutional Foundations Of Comparative Advantage. Oxford (UK), Oxford University Press: 1-68.

Hall, Peter A. and Kathleen Thelen. 2006. "Institutional Change in Varieties of Capitalism". Paper Presented For Presentation To The Europeanists Conference [Online]. Available From: http://www.Europanet.Org/Pub/Papers/Thelenhall.Pdf. [Accessed 14th January 2008].

Hancké, Bob, Martin Rhodes and Mark Thatcher. 2007. "Introduction: Beyond Varieties of Capitalism”. In Hancké, Bob, Martin Rhodes, and Mark Thatcher (eds.) Beyond Varieties of Capitalism: Conflict, Contradictions and Complementarities in the European Economy. Oxford: Oxford University Press, 3-39.

Hyman, Richard. 2010. "Social Dialogue and Industrial Relations during the Economic Crisis: Innovative Practices or Business as Usual?". Working Paper 11. Industrial and Employment Relations Department, ILO, Geneva.

INE/GSEE-ADEDY 2010. The Greek Economy and Employment: Annual Report: 2010. Athens: INEGSEE.

Jessop, Robert D. 2012. Traditionalism, Conservatism and British Political Culture. Routledge, London.

Jessop, Robert D. 2011. "Rethinking the Diversity and Variability of Capitalism: On Variegated Capitalism in the World Market", In Christel Lane and Geoffrey Wood (eds.), Capitalist Diversity and Diversity within Capitalism. London: Routledge, 209237.

Kapsalis, Apostolos. 2007. "Undeclared Work and Legalisation Issues of Immigrants: The Challenge of Immigration Policy”. Athens: INE/GSEE-ADEDY.

Katsios, Stavros. 2006. "The Shadow Economy and Corruption in Greece". SouthEastern Europe Journal of Economics, 1: 61-80.

Klein, Naomi. 2007. The Shock Doctrine. London: Macmillan.

Kokkaliari, Katerina. 2010a. "Enhancement of Flexible Forms of Employment". Ethnos Newspaper, $21^{\text {st }}$ August 2010: 34-35.

Kokkaliari, Katerina. 2010b. "Changes in Employment Relations". Ethnos Newspaper, $17^{\text {th }}$ June 2010: 4-5.

Kollias $\dagger$, Christos, George Manolas and Suzanna-Maria Paleologouc. 2004. "Military Expenditure and Government Debt in Greece: Some Preliminary Empirical Findings". Defence and Peace Economics, 15 (2), 1-21.

Kollias, Christos and Suzanna-Maria Paleologou. 2010. "Growth, Investment and Military Expenditure in the European Union-15", Journal of Economic Studies, 37 (2), 228-240.

Kornelakis, Andreas and Horen Voskeritsian. 2014. "The Transformation of Employment Regulation in Greece: Towards a Dysfunctional Liberal Market Economy?". Relations industrielles/Industrial Relations, 69 (2), 344-365

Koukiadaki, Aristea and Lefteris Kretsos. 2012. "Opening Pandora's Box: The Sovereign Debt Crisis and Labour Market Regulation in Greece". Industrial Law Journal, 41 (3), 276-304.

Kouzis, Yiannis. 2007. The Characteristics of the Greek Trade Union Movement Divergence and Convergence with Europe. Athens: Gutenberg.

Kouzis, Yiannis. 2009. "The Panorama of Work Insecurity and Precarious Employment." Epochi, 52, Published on 22 November 2009, Official Website: http://entosepoxhs.wordpress.com/2009/11/.

Kretsos, Lefteris. 2004. "Industrial Relations and Undeclared Work." EIRO. Online: European Industrial Relations Observatory On-Line, INE/GSEE-ADEDY. 
Available From:

http://www.eurofound.europa.eu/eiro

/2004/06/Tfeature/Gr0406104t.htm.

Kretsos, Lefteris. 2011a. "Union Responses to the Rise of Precarious Youth Employment in Greece." Industrial Relations Journal, 42 (5), 453-472.

Kretsos, Lefteris. 2011b. "Grassroots Unionism in the Context of Economic Crisis in Greece". Labour History, 52 (3), 265-286.

Kritsantonis, Nicos 1998. "Greece: The Maturing of the System”. In Ferner, Anthony and Richard Hyman (eds) Changing Industrial Relations in Europe, $2^{\text {nd }}$ Edition. Oxford: Blackwell Publishers, 504-528.

Kyrgidou, Lida P. and Stavroula Spyropoulou. 2013. "Drivers and Performance Outcomes of Innovativeness: An Empirical Study." British Journal of Management, 24 (3), 281-298.

Lane, Christel and Wood, Geoffrey. 2009. "Diversity in Capitalism and Capitalist Diversity." Economy and Society, 38 (4), 531-551.

Lynn, Matthew. 2010. Bust: Greece, the Euro and the Sovereign Debt Crisis. London: Wiley.

Marginson, Paul, Keith Sisson, James Arrowsmith and Harry Charles Katz. 2006. European Integration and Industrial Relations: Multi-Level Governance in the Making. Hampshire (UK): Palgrave Macmillan.

Matsaganis, Manos. 2007. "Union Structures and Pension Outcomes in Greece." British Journal of Industrial Relations, 45 (3), 537-555.

Matsaganis, Manos. 2012. "Social Policy in Hard Times: The Case of Greece". Critical Social Policy, 32 (3), 406-421.

Mihail, Dimitrios M. 2003. "Atypical Working in Corporate Greece." Employee Relations, 25 (5), 470-489.

Mihail, Dimitrios M. 2004. "Labour Flexibility in Greek Smes." Personnel Review, 33 (5), 549-560.

Mihail, Dimitrios M. and Kristina Antigoni Elefterie. 2006. "Perceived Effects of an MBA Degree on Employability and Career Advancement: The Case of Greece." Career Development International, 11 (4), 352-361.

Molina, Oscar and Melina Rhodes 2007. "The Political Economy of Adjustment in Mixed Market Economies: A Study of Spain and Italy." In Hancké, Bob, Martin Rhodes, and Mark Thatcher (eds.) Beyond Varieties of Capitalism: Conflict, Contradictions and Complementarities in the European Economy. Oxford: Oxford University Press, 3-39. 223-252.

Mof 2010a. Greece - Memorandum Of Economic and Financial Policies. 6 August 2010. Athens, Ministry of Finance.

Mof 2010b. Greece - Memorandum Of Economic and Financial Policies. 22 November 2010. Athens, Ministry of Finance.

Mulhern, Alan. 1995. "The SME Sector in Europe: A Broad Perspective". Journal of Small Business Management, 33 (3), 83-88.

Nash, David. 2011. "Institutions, Investors and Managers: The Impact of Governance on the Employment Relationship." In Blyton, Paul, Edmond Heery, and Peter Turnbull (eds.). Reassessing the Employment Relationship. Houndmills: Palgrave Macmillan, 225-248.

OECD. 2007. Economic Survey of Greece. Paris: OECD, Available From: http://www.Oecd.Org/Dataoecd/57/24/38665552.Pdf

OECD. 2008. Employment Outlook. Paris: OECD.

OECD. 2009. Economic Survey of Greece. Paris: OECD, Available From: http://www.Oecd.Org/Dataoecd/5/61/43284926.Pdf 
Priestland, David (2012). Merchant, Soldier, Sage: A New History of Power. London: Fontana.

Psychogios, Alexandros, Leslie T. Szamosi and Geoffrey Wood. 2010. "Introducing Employment Relations in South Eastern Europe." Employment Relations, 32 (3), 205211.

Psychogios, Alexandros and Geoffrey Wood 2010. "Human Resource Management in Comparative Perspective: Alternative Institutionalist Perspectives and Empirical Realities." International Journal of Human Resource Management, 21 (14), 26142630.

Psychogios, Alexandros, Nikos Michalopoulos and Leslie T. Szamosi. 2008. "AngloSaxon Change in a Non-Anglo-Saxon Cultural Context: Lessons from TQM Application in Greek Public Organizations." International Journal of Learning and Intellectual Capital. 5 (2), 153-171.

Psychogios, Alexandros and Leslie T. Szamosi 2007. "Exploring the Greek National Business System: Towards a Modernization Agenda." Euro Med Journal of Business, $2(1), 7-22$.

Rhodes, Martin 1995. "A Regulatory Conundrum: Industrial Relations and the Social Dimension". In Leibfried, Stephan and Paul Pierson (eds.). European Social Policy: Between Fragmentation and Integration. Washington DC: Brookings Institution.

Reuters. 2015. "Greek Parliament Approves Bailout Measures as Syriza Fragments." Available from: http://www.reuters.com/article/2015/07/16/us-eurozone-greeceidUSKBNOP40EO20150716.

Schmidt, Vivien A. 2002. The Futures of the European Capitalism. Oxford: Oxford University Press.

Schmidt, Vivien A. 2007. "Bringing the State Back into the Varieties of Capitalism and Discourse Back into the Explanation of Change". Minda De Gunzburg Center For European Studies Working Paper Series 152.

Scott, James P. 2001. "Does UK Defence Spending Crowd-Out UK Private Sector Investment?", Defence and Peace Economics, 12 (4), 325-366.

Sorge, Arndt 2005. The Global and the Local. Oxford: Oxford University Press.

Streeck, Wolfgang. 2011. "The Crises of Democratic Capitalism", New Left Review, 71, 5-29.

The Guardian. 2015 "Greek debt crisis: deal reached after marathon all-night summit."

Available

from: http://www.theguardian.com/business/live/2015/jul/12/greek-debt-crisis-euleaders-meeting-cancelled-no-deal-live\#block-55a382dde4b05111b7559d81.

Vasiliou, Dimitrios and Nikolaos Daskalakis. 2009. "Institutional Characteristics and Capital Structure: A Cross-National Comparison." Global Finance Journal, 19 (3): 286-306.

Voskeritsian, Horen and Andreas Kornelakis. 2011 "Institutional Change in Greek Industrial Relations in an Era of Fiscal Crisis." Greece Paper No. 52 Hellenic Observatory Papers on Greece and Southeast Europe.

Vouzas, Fotis. 2004. "HR Utilization and Quality Improvement: The Reality and the Rhetoric- The Case of Greek Industry." The TQM Magazine, 16 (2), 125-135.

Wall Street Journal. 2015. "Eurozone Leaders Reach Rescue Deal for Greece, with Tough Conditions." July 13, 2015 (online).

World Bank. 2014. "Military Expenditure (\% of GDP)." Available from: http://Data.Worldbank.Org/Indicator/MS.MIL.XPND.GD.ZS.

Zambarloukou, Stella. 2006. "Collective Bargaining and Social Pacts: Greece in Comparative Perspective". European Journal of Industrial Relations, 12 (2), 211-230. 
Zambarloukou, Stella. 2007. "Is there a South European Pattern of Post-Industrial Employment?" South European Society and Politics, 12 (4), 425-442.

Zambarloukou, Stella. 2010. "Ownership, Corporate Governance and Industrial Relations in the Banking and Telecommunications Sector: The Case of Greece." Industrial Relations Journal, 41 (3), 233-248. 